\title{
HUMANISTIČKO - EKOLOŠKA DIMENZIJA U TEORIJSKIM POLAZIŠTIMA VASPITANJA I OBRAZOVANJA ZA ODRŽIVO DRUŠTVO ${ }^{6}$
}

\begin{abstract}
Apstrakt
Prateći savremene trendove $u$ distribuciji znanja, pedagogija u holističkom duhu poimanja sveta, uspostavlja sve tešnje veze i odnose sa ekologijom. Na osnovu tih interakcija $i$ sveobuhvatne interpretacije pedagoškog diskursa $u$ ekologiji $i$ ekološkog diskursa $u$ pedagogiji nastaje i koncept ekopedagogije. Ekopedagogija izrasta na ekološkom vaspitanju $i$ obrazovanju koje ima za cilj da kod pojedinca razvije ekološku svest, omogući sagledavanje inicijalnog stanja, ali i da pruži perspektivu i strategiju za buduće naraštaje, koji će svoje uporište imati upravo u održivom društvu. Reč je o društvenom idealu koji treba da dovede do poboljšanja uslova života na ekonomskom i drušvenom planu bez narušavanja prirodnog ekvilibrijuma. Baveći se analizom ovog filozofskog, teorijskog i praktičnog konstrukta u radu je dat prikaz ekopedagoških strujanja, sa posebnim osvrtom na humanističko-ekološku dimenziju u sublimiranim teorijskim polazištima vaspitanja i obrazovanja za održivo društvo. $U$ radu je takođe data analiza relevantne osnove za konceptualizaciju vaspitanja $i$ obrazovanja za održivo društvo u vidu teorijskih polazišta poput Ekološke etike, Socijalne ekologije, Socijalnog konstruktivizma i Bronfenbrenerove ekološke teorije.
\end{abstract}

Ključne reči: ekologizacija vaspitanja i obrazovanja, ekopedagogija, održivo društvo, socijalna ekologija, socijalni konstruktivizam.

\footnotetext{
5 stashamaric@ff.uns.ac.rs

${ }^{6} \mathrm{Rad}$ je nastao kao rezultat istraživanja u okviru projekta „Kvalitet obrazovnog sistema Srbije u evropskoj perspektivi (KOSSEP), (br.179010), koji finansira Ministarstvo za nauku i tehnološki razvoj Republike Srbije“
} 


\section{Uvod}

Aktuelni potrošački koncept života, materijalističko društvo današnjice i politike koje se vode stavili su svet pred ozbiljan problem nazvan „ekološka kriza”. Upravo iz tog razloga, ukoliko se želi osigurati budućnost narednim pokolenjima neminovno je promeniti „filozofiju življenja’'. Savremeno društvo ulazi u eru ekologizacije i humane ekologije. Ekologizacija podrazumeva spoj ekoloških i humanističkih sadržaja, prirodno - tehnoloških i društveno-humanističkih nauka sa tendencijom održivosti i permanentnosti dok se humana ekologija u najširem smislu tretira kao istraživačko usmerenje ekologije koje proučava interakciju čoveka sa okolinom (Cifrić, 2012).

$\mathrm{Na}$ svetskom samitu Ujedinjenih nacija 2005. godine jedan od donetih zaključaka odnosio se i na razvoj vaspitno-obrazovne prakse u cilju unapređivanja održivog razvoja još od ranog uzrasta. Održivi razvoj definiše se kao idealno-tipski konceptualni pristup gde dominira ideja održivosti, koja pronalazi ravnotežu između ekonomske produktivnosti, socijalne kohezije i ekološke stabilnosti (Cifrić, 2012). Kao posebni izazovi za profesionalce koji se bave vaspitanjem i obrazovanjem u savremenom društvenom diskursu istakli su se razvoj obrazovnog sistema, kurikulum i pedagoška praksa koji bi bili održivi u tri segmenta održivog razvoja. Reč je o socijalnom razvoju, ekonomskom razvoju i očuvanju životne sredine. Ova tri „stuba” održivog razvoja moraju po definiciji participirati ravnopravno i kohezivno u praksi, u suprotnom su osuđeni na neuspeh (Siraj- Blatchford, 2009). Obrazovanje za održivi razvoj je specifično pre svega po svom cilju i suštini, i u skladu sa tim princip njegove konceptualizacije je sličano obrazovanju za mir, obrazovanju za demokratiju, građanskom obrazovanju... (Siraj-Blatchford, 2009; Öhman, 2007 prema Hägglund, \& Pramling Samuelsson, 2009). Po ovoj definiciji vaspitanja i obrazovanja za održivo društvo, to praktično znači da ono mora počivati na vrednostima kao što su demokratija, solidarnost, tolerancija, jednakost i pravda. U skladu sa tim, u vaspitnoobrazovnoj praksi, neophodno je koncipirati kurikulume koji bi osigurali socijalni i intelektualni razvoj dece. Kurikulum koji ima uticaj samo na razvoj saznajnih i intelektualnih potencijala dece nije održiv, a upravo mu socijalno-emocionalna komponenta pridaje dimenziju „održivosti” utičući na razvoj moralnosti, samodiscipline i etike kod dece, kao i na vrednosti i stavove. Od deteta koje se obrazuje za održivi razvoj očekuje se da postane osoba sa sposobnošću da se suoči sa kompleksnim i ozbiljnim istinama o životu. Ova deca imaju pravo da zahtevaju ozbiljne napore od odgovornih odraslih i institucija od kojih se očekuje da stvore efikasne kontekste za učenje o premisama za održivost (Hägglund, \& Pramling Samuelsson, 2009). 
U radu su analizirana teorijska polazišta, koja po mišljenju autora mogu imati značajne implikacije na redefinisanje pedagoške prakse, ukoliko bi iste postale njena okosnica uz neophodno uvažavanje ostalih postulata obrazovanja za 21.vek.

\section{Ekologizacija vaspitanja i obrazovanja}

Sa novim vekom, dolazi i nova paradigma vaspitanja i obrazovanja, jer istorija nam je do sada pokazala da je sve promenljivo osim same potrebe za promenom. Paradigma ekologizacije vaspitanja i obrazovanja javila se kao mehanizam pomoću kog su se formirale i razvile ekopedagogija i ekološka kultura. Osnovne postavke utemeljenja ove paradigme su odgovornost čoveka koju ima prema sudbini Zemlje, nastojanje da se razume jedinstvo i celovitost sveta, kao i uspostavljanje dijaloga između prirode i čoveka. Iz takvih postavki proizašlo ekološko vaspitanje i obrazovanje ima zadatak da se kao proces transformiše u nekoliko pravaca: od jednosmernog komunikacionog odnosa i siromašne interakcije ka odnosima saradnje, bogate socijalne interakcije i dvosmerne komunikacije; od parcijalizovane predmetne nastave ka integralno didaktičkom pristupu; od jednoobraznog formalnog sistema do raznovrsnih obrazovnih ustanova, alternativnih nastavnih programa $\mathrm{i}$ modela (Klemenović, 2004:107). Cifrić ekopedagogiju definiše kao opus svih ekopedagoških strujanja koja polaze od nužnosti radikalnih promena bazičnih predstava o društvu, ulozi vaspitanja i obrazovanja i odnosima čovek - priroda. U kontekstu ekološke i obrazovne krize iznedrile su se različite spone između pedagogije i ekologije te različiti pristupi u pedagoškoj interpretaciji ekoloških pitanja, te je osim ekološkog vaspitanja i obrazovanja nastala i ekopedagogija kao sveobuhvatna interpretacija pedagoškog diskursa u ekologiji (Cifrić, 2012).

Savremeno ekološko obrazovanje obeleženo je postulatima pedagogije doživljaja i inovacijama u metodama rada, te usklađivanjem sa zahtevima ekoloških organizacija $u$ zajedničkoj brizi za okolinu. U literaturi se ono pominje i kao „socio-ekološko obrazovanje o okolini', Akcenat je na odgovornom delanju pojedinca u društvu u skladu sa socijalnim normama (Andevski, \& Knežević - Florić, 2002 prema Marić Jurišin, 2011).

Određenja ekološkog vaspitanja su: upoznavanje sa delovanjem koje čovek ima na životnu sredinu u obliku različitih formi i dimenzija; sticanje veština, znanja, navika i stavova o ekološkim osobenostima, zakonima i procesima u životnoj sredini; razumevanje dostignuća i težnji tehnologije, društvenih nauka i umetnosti u pogledu unapređenja i zaštite životne sredine; navikavanje na adekvatan odnos prema kulturnim vrednostima, objektima u prirodi, 
vrednostima koje su stvorene radom, kao i prema ukupnim međuljudskim odnosima. Kao osnovni produkt tako koncipiranog ekološkog vaspitanja i obrazovanja u literaturi se navodi ekološka svest. Prema Cifriću (2012) ekološka svest je svest o nužnosti ukidanja dominacije čoveka nad prirodom u njenom izvornom kao i socijalno konstituiranom obliku i uspostavljanju ravnoteže između prirodnih sistema i čovekovog sistema. Pojam ekološke svesti obuhvata sledeće aspekte: obrazovni, vaspitni, aksiološki, politički i delatni aspekt.

\section{Održivo društvo - društvo koje (p)ostaje}

Održivi razvoj i održiva zajednica javljaju se kao moguće rešenje značajnog problema današnjice, a kao cilj se ističe zadovoljavanje potreba sadašnjosti bez bojazni da buduće generacije neće moći da zadovolje svoje potrebe. Održivost je obavezujuća kako prema prirodi, tako i prema čoveku. Ona ne predstavlja neki gotov program, već koncept koji povezuje sve činioce jednog društva i pomoću njih daje smernice za delovanje pojedinca kako na globalnom, tako i na lokalnom nivou. U tom smislu, održivost je etički imperativ koji ima za cilj: humanističke vrednosti, ekonomsku izdržljivost, kulturni identitet, vraćanje prirodi, pravednost, samoostvarenje, globalnu povezanost, partnerstvo... Sa naučnog stanovišta, čini se da se radi o utopiji savremenog doba, novoj paradigmi i ključnom faktoru za promene u vaspitanju i obrazovanju.

U suštini održivi razvoj je proces promena unutar koje su eksploatacija resursa, usmeravanje investicija, orijentacija tehnološkog razvoja $\mathrm{i}$ institucionalne promene $\mathrm{u}$ harmoniji i omogućavaju korišćenje sadašnjih i budućih potencijala kako bi se zadovoljile ljudske potrebe i aspiracije (World Commission on Environment and Development, 1987 http://www.freewebs.com/odrzivirazvoj/VIII\%20cas.pdf).

Prema Cifriću (2012) put u održivo društvo, a samim tim i održivu zajednicu, povezan je sa promenom industrijskog metabolizma, što u stvari znači revalorizovanje uloge tehnike i celokupnog kulturnog okruženja. Ovakvo društvo je dinamično u zavisnosti od razvojnih mogućnosti koje će uticati na njegovo stalno održivo preoblikovanje. Održivu zajednicu predstvalja društvo koje je socijalno, ekonomski i ekološki zdravo. Takvo društvo postavljene izazove zadovoljava integrisanim rešenjima, a ne fragmentarno ispunjavanjem jednog od ciljeva na uštrb drugih. Možemo da zaključimo da se održiva zajednica bazira na kako na aktuelnoj situaciji tako i na viziji budućnosti. 


\section{Obrazovanje za održivo društvo}

Održivo društvo predstavlja ono društvo koje može da napreduje bez ozbiljnijih neuspeha u doglednoj budućnosti. Ova istorijska faza treba da predstavlja period kada je društvo postalo zrelo i prihvatilo da bude održivo, što podrazumeva preuzimanje kako lične, tako i kolektivne odgovornosti, uz poštovanje drugih, razvoj empatije, ljubavi, pripadanja i brige. To je aktuelna faza u razvoju ekološkog vaspitanja i obrazovanja koja stremi obrazovanju za zaštitu životne sredine u odnosu na obrazovanje za zaštitu prirode i obrazovanje za održivo društvo u odnosu na obrazovanje za održivi razvoj.

Obrazovanje za održivo društvo daje mogućnost svakome da stekne znanja, umenja, vrednosti i stavove koji su neophodni kako bi sam mogao da oblikuje održivu budućnost. Ono podrazumeva uključivanje najvažnijih pitanja o održivoj zajednici i razvoju u nastavnoobrazovni proces. Tu spadaju: održiva potrošnja, smanjenje siromaštva, smanjenje rizika od katastrofa, klimatske promene, biodiverzitet i slično, a takođe zahteva inkorporiranje određenih metoda rada koje će delovati stimulativno na motivisanost dece da promene svoje ponašanje i počnu da se ponašaju odgovorno kako bi osigurali održivi razvoj, tj. održivo društvo.

Važnost obrazovanja za održivo društvo vidimo i u jednoj od tema kojom se bavi UNESCO, a to je „Nauka za održivu budućnost”. Ovde se ističe značaj povezanosti društva sa naukom, gde je shvatanje nauke i učešće građana u nauci od krucijalne važnosti za koncept društva u kom ljudi poseduju neophodna znanja kako bi svoje lične, profesionalne, političke i svake druge izbore bili u stanju da upotrebe u svetu otkrivanja.

Vaspitanje i obrazovanje za održivo društvo usmereno je pre svega na razvoj ekološke svesti, empatije, solidarnosti, socijalne i ekološke odgovornosti, zrelosti i autonomije, kompetencije, sposobnosti samooblikovanja i jačanja ličnosti, što zahteva i određene reforme aktuelnog kurikuluma.

\section{Teorijska polazišta vaspitanja i obrazovanja za održivo društvo}

Osnovni postulati ekologizacije u duhu nove obrazovne paradigme imaju sledeće odrednice: ekološka znanja nisu znanja koja za ishod imaju školska postignuća već znanja koja obezbeđuju budućnost; učenje se odvija kroz interakciju deteta sa okolinom, što direktno utiče tj. određuje šta će i u kojoj meri dete internalizovati; neophodna je interakcija između individualnih životnih snaga i obrazovnog dobra šta moraju da prate relevantne aktivnosti 
koje kao nosioci učenja doprinose ličnom oslobađanju i razvoju ličnosti; neophodno je uspostaviti istovetno funkcionisanje kognitivnih i nekognitivnih procesa učenja.

Značajan uticaj na formiranje vaspitanja i obrazovanja za održivo društvo predstavljaju teorije na kojima ono počiva, te se zbog toga poseban akcenat stavlja na sagledavanju pomenutih uticaja i njihovo sadejstvo. Izabrana i predstavljena teorijska polazišta doprinose u najvećoj meri upravo pomenutoj ispravnosti delovanja, činjenja i ostvarenja, odnosno ekološkog osvešćenja. Relevantnu osnovu za konceptualizaciju vaspitanja i obrazovanja za održivo društvo imaju sledeća teorijska polazišta: Ekološka etika, Socijalna ekologija, Socijalni konstruktivizam i Bronfenbrenerova ekološka teorija. Upravo su ovo i moguća polazišta za dimenzioniranje kurikuluma za održivo društvo koja u fokusu imaju promenu vrednosne orjentacije.

\section{Ekološka etika}

Prema mišljenu A. Kirn (Kirn, 1986: 294), naučna i filozofska misao su postale predmet ekološke kritike jer predstavljaju zaleđinu današnje tehnološke, ekonomske i društvene prakse, čiji se negativni ekološki učinci dovode u vezu sa antiekološkim načinom mišljenja klasične nauke, njenim metodama ispitivanja i modelima konstruisanja sveta. Kako bi prevazišao postojeće stanje, savremeni čovek je u situaciji da oslonac potraži u „Zahvatanju apsolutnog" i suočavanju sa „istinom koja se tiče celine bitka”, odnosno u filozofskom promišljanju ekološke krize i njenom mestu u okviru filozofije istorije ljudske kulture. Otuda u središte analize filozofsko-ekološkog diskursa ulaze ne samo pojam prirode već i vrednosni stavovi o odnosima čoveka i prirode (Hősle, 1996 prema Klemenović, 2007a). Kao najprimereniji model u ovakvom tumačenju sveta uzima se holističko, ekološki model, koji se prema Sterlingu zasniva na interaktivnom karakteru čovekovog odnosa prema svetu. Ekološko-holističko viđenje sveta se može tretirati i kao organsko, participativno i ekocentrično (Klemenović, 2007a).

Svoje uporište ekološka etika pronalazi u sistemu vrednosti iz kojeg izrasta. Takva vrednosna orijentacija jednog društva ima značajan uticaj na sveukupne promene u vaspitnoobrazovnom sistemu i čovečanstvu uopšte. Odnos obrazovanja i vrednosti je međuzavistan. Dok sa jedne strane obrazovanje kreira vrednosti, sa druge strane ono predstavlja socijalnu praksu koja ih prenosi i implementuje (Tuomisto, 1990 prema Milutinović, 2008). Upravo je iz ovog razloga za obrazovanje izuzetno značajna aksiologija. Aksiologija se bavi ispitivanjem i proučavanjem opštih karakteristika svih oblika vrednosti. Ona, prema navodu 
Životića (Životić 1986:23 prema Milutinović, 2008), ispituje njihove uzajamne odnose, uslove nastanka, forme i sadržaje oblikovanja, uslove važenja i promene sadržaja, kao i procenu samih vrednosti. Polazeći od postavke da prema vrednostima usmeravamo svoje izbore i ponašanje uopšte, a shodno tome i sudimo, evidentan je njihov značaj i mesto u obrazovnom sistemu prilikom formulisanja i izbora sadržaja, ciljeva, oblika i metoda rada, te evaluacije vaspitno-obrazovnog procesa. Svaki kurikulum se zasniva na vrednosnim matricama čiji je cilj da budu usvojene u toku vaspitno-obrazovnog procesa. "Održivi kurikulum temelji se na etičkom diskursu koji ima za cilj da deci pomogne da nauče kako da artikulišu vlastita verovanja i osećanja, kao i da nauče da poštuju različitost među pojedincima i grupama. Na taj način, deca treba da učestvuju u oblikovanju multietničke, ekološke, antirasističke i nepatrijarhalne vizije demokratske zajednice” (Milutinović, 2008: 173).

Posebno važan društveno-personalni proces koji doprinosi uspostavljanju i formiranju ekološke kulture, zasnovane na ekološkoj umnosti, ekološkoj svesti i ekološkoj etici, predstavlja proces vaspitanja i obrazovanja u kome je ekološka dimenzija naročito naglašena, odnosno proces ekološkog vaspitanja i obrazovanja (Klemenović, 2007b: 383).

\section{Socijalna ekologija}

Stalne promene u savremenom društvu doprinele su da se ekološka problematika prenese sa biološkog na socijalno polje, a njen predmet proučavanja proširi sa lokalnog na globalni, odnosno svetski nivo. Tako se pored „biološke, medicinske, humane, političke” sve više govori o „socijalnoj ekologiji” (Mišković, 2013). Ivan Cifrić (2012) socijalnu ekologiju definiše kao sociološki, odnosno ekološki intoniranu disciplinu koja prevazilazi sociološka i ekološka ograničenja predmeta i metoda. U njenom razvoju značajnu ulogu imala je čikaška škola kojoj se pripisuje termin Humana ekologija. Navode ga Park i Burges i oni pod socijalnom ekologijom podrazumevaju ekološki način promatranja ljudskog društva sa akcentom na planiranje velikih gradova. Kasnije, na razvoj socijalnoekološkog pristupa uticale su i neke okolnosti u prirodnim i društvenim naukama poput: 1) disciplinarnog približavanja prirodnih i društvenih (humanističkih) nauka usled porasta kompleksnosti predmeta istraživanja; 2) upotrebe pojma sistem u prirodnim i socijalnim naukama; 3) nastanka ekološke krize i pomaka u pronalaženju uzroka i rešenja od biološkog prema socijalnom području; 4) globalizacije ekoloških i socijalnih problema od lokalnog prema globanom nivou pa se i ekologija shvata kao globalna ekologija (Glavač, 2011). 
Socijalnu ekologiju možemo smatrati proizvodom ,povezivanja” društvenih i prirodnih nauka. Određen broj teoretičara smatra da je reč o sociologiji sa ekološkim predmetom istraživanja, dok drugi smatraju da se radi o ekologiji sa društvenim predmetom istraživanja, te da se ona bavi ispitivanjem uzajamnih odnosa socijalnog ponašanja ljudi i njihove okoline. Socijalna ekologija tretira se i kao teorija formiranja i funkcionisanja (Markov, 1986). U suštini ona polazi od pretpostavke da ekološki problemi imaju uzroke u društvu i da zbog toga i moraju da budu rešeni od strane društva. Što za posledicu ima nužnost promene dosadašnje razvojne paradigme u socijalnopedagošku paradigmu.

Socijalna ekologija je u sprezi sa pojmovima kao što su ekozofija, socijalnopedagoška paradigma, ekopedagogija, ekološko obrazovanje i ekološko vaspitanje. Socijalnoekološku paradigmu čine istraživanja odnosa društva i prirode u individualnom i društvenom delovanju. Ovde je značajno da istaknemo da se u dualističkom shvatanju sveta $u$ većini kultura stvarni život zajednice odvija upravo prema socijalnoekološkoj paradigmi. Pored jedinstva prirode i kulture, u ovoj paradigmi se visoko kotiraju i razvojna pitanja, vaspitanje i obrazovanje, odnos prema životu, promena sistema vrednosti i socijalnoekološka ravnoteža. Socijalna ekologija u svojim učenjima sublimira znanja i pojmovna određenja iz različitih nauka poput sociologije, pedagogije, filozofije, antropologije, ekologije, biologije, psihologije, teologije i drugih (Cifrić, 2012).

\section{Socijalni konstruktivizam}

Obrazovanje za održivi razvoj polazi od shvatanja da sadržaj učenja ne treba da bude dat, nego da dete treba da ga samo konstruiše i izgrađuje uz pomoć vaspitača/nastavnika. Kada je reč o konstruktivizmu, neophodno je praviti razliku između socijalnog konstruktivizma Vigotskog i psihološkog konstruktivizma Pijažea. Iako oba polaze od postavke samostalne misaone aktivnosti deteta, psihološki konstruktivizam Pijažea akcenat stavlja na individualne aktivnosti, a socijalni konstruktivizam Vigotskog na socijalne aktivnosti deteta. Suštinska razlika između konstruktivizma i ko-konstruktivizma je u tome što predstavnici prve teorije polaze od premise da se ključne razvojne promene $u$ kognitivnom razvoju formiraju unutar individue, dok ko-konstruktivisti polaze od pretpostavke da se ključne promene u kognitivnom razvoju dece izgrađuju u okviru interakcije sa drugima da bi se potom individualizovale (Baucal, 2003). Iako konstruktivisti u centar stavljaju dete kao aktivnog mislioca i stvaraoca u procesu učenja, ne zanemaruju ni 
ulogu vaspitača, odnosno učitelja. Oni predstavljaju potporu i podršku i stvaraju podsticajnu sredinu u kojoj deca mogu da se razvijaju i napreduju.

Konstruktivizam se posmatra kao heterogen skup teorijskih pristupa u različitim naučnim oblastima (Vianna \& Stetsenko, 2006) pri čemu se u domenu filozofije izazov konstruktivizma najčešće svodi na preispitivanje održivosti dve temeljne tvrdnje naučnog realizma (Stojanov, 2005). Prva podrazumeva da objekti saznavanja postoje nezavisno od uma onoga koji saznaje, a druga da naučne teorije predstavljaju istinu o objektivnom svetu (Milutinović, 2011: 178). S obzirom da su ekološko vaspitanje i obrazovanje neodvojivi od socio-kulturnog konteksta, kao osnovu ovakvog učenja i procesa formiranja znanja možemo da istaknemo baš socijalni konstruktivizam. Osnovna premisa socijalnog konstruktivizma je mentalna aktivnost deteta, koja ne može biti odvojena od kulturnog i socijalnog okruženja. Socijalni konstruktivizam usmeren je na interpsihičke procese, odnosno na oblike i sadržaje diskursa među individuama. Ova teorija naglašava ulogu kulture i društva u vaspitnoobrazovnom procesu. Smatra se da upravo socijalna zajednica i kultura formiraju načine na koje individua percipira i interpretira značenja koja pripisuje svom vlastitom iskustvu. Shodno tome socijalni konstruktivizam tretira znanja kao proizvod socijalnih procesa i upotrebe jezika (Jordan et al., 2008 prema Milutinović, 2011). Značaj uvođenja ove ideje, socijalnog konstruktivizma, u ranom uzrastu odnosi se na smeštanje individualnog u socijalni kontekst. Najvažnije promene u dečijem razvoju odnose se na socijalne procese i odnose koji omogućavaju dodeljivanje određenog značenja unutar same grupe i na kraju njihovu internalizaciju od strane pojedinih članova. Na ovaj način dete može aktivno da konstruiše svoja znanja $u$ interakciji sa okolinom, a pri tom se okolina, ljudi i sami njihovi odnosi menjaju.

\section{Bronfenbrenerova ekološka teorija ljudskog razvoja}

Polazeći od hipoteze da je vrsta Homo sapiensa veoma elastična, promenljiva, te sposobna da se prilagodi, toleriše i stvori sredinu u kojoj će rasti i razvijati se, tvorac ove teorije, Juri Bronfenbrener (Bronfenbrenner, 1997) naglašava da se pomenuti ljudski razvoj i promene ne mogu posmatrati van konteksta grupe, zajednice, društva i kulture kojoj pojedinac pripada. Bronfenbrenerova teorija ekoloških sistema polazi od pretpostavke da je u razmatranju razvoja potrebno razmotriti dvosmerno delovanje deteta i okoline u kojoj ono raste. Razvoj je predstavljen kao trajna promena načina na koji individua doživljava sredinu i odnosi se prema njoj, dok se ekološko okruženje (sredina) opaža kao set struktura od kojih je 
svaka smeštena u narednu, dok je osoba koja se razvija smeštena u njihovo jezgro. Kako bi ustanovili da li je i došlo do razvoja individue, potrebno je da se ustanovi da li se promene $u$ aktivnostima i koncepcijama iste prenose i u druga vremena i druga okruženja.

Bronfenbrener smatra da dete i okolina neprekidno utiču jedno na drugo na dvosmeran, transakcijski način (Bell, Sameroff, prema Vasta, Haith, Miller, 2005: 60). Ekosistem (okolina) transakcijskim (interaktivnim) putem na dete (čoveka) deluje kroz mikrosistem (okolina najbliža detetu: porodica, vrtić, škola, crkva, igralište...), mezosistem (sistem koji povezuje više detetovih mikrosistema, npr. roditelje i učiteljicu), egzosistem (socijalna okruženja u kojima dete neposredno ne učestvuje: lokalna vlast, školsko veće...) i makrosistem (kultura i subkultura u kojoj dete živi: država - zemlja, pojedini delovi zemlje...) (Vasta-Haith, \& Miller, 2005: 59-61). Ovi su sistemi međusobno povezani kronosistemom koji je „... struktura događaja iz okoline i promena tokom života, kao i sociokulturalne okolnosti'” (Santrock, 2008 prema Eret, 2012: 143-144).

Razvojni potencijal okruženja, prema ekološkoj teoriji, povećava se kada zatvorenu mrežu aktivnosti čine osobe uključene u zajedničke aktivnosti. Ovaj sklop postaje optimalan ukoliko je svaki član u interakciji sa svim ostalim članovima u svim okruženjima i ako je ispunjen uslov da se raspodela moći postepeno menja u korist osobe koja je u razvoju (Bronfenbrener, 1997). Ekologija ljudskog razvoja tako predstvalja tačku uzajamnog približavanja, odnosno spoja disciplina psiholoških, bioloških i društvenih nauka u onoj meri u kojoj se one odnose na razvoj individue u određenom društvu.

\section{Zaključak}

Ideja o ekološkom vaspitanju i obrazovanju nastala je podstaknuta dokumentima, strategijama i deklaracijama koje su donete od strane velikog broja međunarodnih organizacija od nacionalnog i regionalnog značaja (UNESCO, UN, OECD, UNEP), sa jedne strane, kao i primerima efikasne prakse ekološkog vaspitanja i obrazovanja u različitim zemljama u svetu, sa druge strane. Na svom razvojnom putu, ekološko vaspitanje i obrazovanje trpelo je različite transformacije u suštinskom smislu. Od „sredstva za gašenje požara' izraslo je u čitavu filozofiju života sa idejom da njegova funkcija postane preventivna, a na kraju da postane i stil života.

Recentan pedagoški imperativ teži pre svega promeni vrednosti, a savremeni društveni diskurs traži novu ulogu vaspitno - obrazovnog sistema. Nijedan fenomen ne može da postoji nezavisno od sistema kojem pripada i delova sa kojima stoji u vezi. Kako 
naglašavaju zagovornici holističkog obrazovanja, uloga vaspitno-obrazovnih institucija je u tome da podstaknu razvoj na svim nivoima, a ne samo da pružaju znanja koja deca treba da usvoje. Stoga bi imperativ ovih institucija trebao da bude dete koje kritički misli, ostvaruje uspešnu komunikaciju i saradnju sa drugom decom i analizira i rešava probleme.

Ekološko-humanistička paradigma nosi u sebi spoj društva, pojedinca i prirode kao i dobrobiti za sve pobrojane. U tom kontekstu ekologija nije samo nauka o suživotu biljnih i životinjskih vrsta i njihovom očuvanju, niti samo o problemima degradacije i iscrpljivanja različitih planetarnih resursa, iznalaženju obnovljivih izvora energije ili reciklaži, već predstavlja koncept života koji održanje svih vrsta i resursa planete stavlja u ruke visoko osvešćenog čovečanstva.

U izgrađivanju te nove etičke perspektive opšte važnosti, koja bi mogla da osigura budućnost naše vrste i omogući razvoj strategije čovečanstva za uspostavljanje i očuvanje ravnoteže između čoveka i prirode, ključnu ulogu ima razvoj ekološke svesti (Marković, 1996: 281). No kako bi se osiguralo pojavljivanje i razvijanje naznačene moralne dimenzije, na razvoj ekološke svesti ne treba gledati kao na sticanje znanja o životnoj sredini, nego više kao na razumevanje prirodnih procesa i njihove uzajamne povezanosti te izgrađivanje pozitivnog odnosa prema životnoj sredini u praksi, u življenju za šta najveća prijemčivost postoji tokom detinjstva (Petrović-Sočo, 2000: 43).

$\mathrm{S}$ obzirom da se osnovom vaspitno-obrazovnog procesa smatra razvijanje $\mathrm{i}$ prenošenje vrednosnih matrica, koje počivaju na podsticanju emocionalnih doživljaja i socijalnih iskustava i doprinose usvajanju moralnih i ekoloških normi održivosti, ekološko vaspitanje i obrazovanje za održivo društvo, bi trebalo da se, s jedne strane, oslanja na postavke Bronfenbrenerove ekološke teorije, a sa druge na postulate sociokonstruktivizma koji predstavlja temelj za komplementarnost različitosti datih entiteta.

Stanislava Marić Jurišin, Novi Sad, Serbia

\title{
HUMANITIES AND ENVIRONMENTAL DIMENSION IN THE THEORETICAL STARTING POINTS OF EDUCATION FOR THE SUSTAINABLE SOCIETY
}

\begin{abstract}
Materialistic society and current politics have led to a serious problem called the "ecological crisis". The analysis of the problems of globalization, individualism and lifestyle lead to a different view of cultural, historical and political circumstances, as well as the
\end{abstract}


pedagogy itself. Following contemporary trends in the distribution of knowledge, pedagogy itself establishes tighter links and relations with ecology, in the spirit of holistic understanding of the World. Based on these interactions and comprehensive interpretation of pedagogical discourse both in ecology and ecological discourse that occurs in pedagogy, the concept of eco-pedagogy has emerged. Eco-pedagogy grows on environmental education that aims to develop environmental awareness in individuals, enable an insight into the initial state, and provide a perspective and strategy for the future generations who will have their stronghold in the sustainable society. The greatest influence on the formation of education for the sustainable society has the theoretical basis on which it has been developed. This paper presents the starting points that mostly contribute to ecological awareness, such as: Ecological Ethics, Social Ecology, Social Constructivism and Brofenbrener's Ecological Theory. These are possible starting points for the design of the curriculum for the sustainable society, which focus on the change in value orientation. We can conclude that if the basis of the educational process is development and the transfer of value matrices, which are based on encouraging emotional and social experiences, ecological education for a sustainable society should rely on the settings of Bronfenbrener's environmental theories, finding its socioconstructive postulates that offer the basis for the complementarity of the diversity entities.

Key words: ecologization of education, eco-pedagogy, sustainable society, social ecology, social constructivism.

\section{Literatura}

Baucal, A. (2003). Konstrukcija i ko-konstrukcija u zoni narednog razvoja: Da li Pijaže i Vigotski mogu biti u pravu? Psihologija, 36(4), 517-542.

Bronfenbrener, J. (1997). Ekologija ljudskog razvoja. Beograd: Zavod za udžbenike i nastavna sredstva.

Cifrić, I. (2012). Leksikon socijalne ekologije. Zagreb: Školska knjiga.

Eret, L. Odgoj i manipulacija: razmatranje kroz razvojnu teoriju ekoloških sustava. Metodički ogledi, 19(1), (2012): 143-161.

Glavač, V. (2001). Uvod u globalnu ekologiju. Zagreb: Hrvatska sveučilišna naklada; Ministarstvo zaštite okoliša i prostornog uređenja; Pučko otvoreno učilište. 
Hägglund, S., \& Pramling Samuelsson, I. (2009). Early childhood education and learning for sustainable development and citizenship. International Journal of Early Childhood, 41(2), 49-63.

Kirn, A. (1986). Tendenca k ekologizaciji znanstvenog mišljenja, družbene zavesti in prake. Pravni vjesnik, 2 (3-4), 107-135.

Klemenović, J. (2004). Ekološko vaspitanje i obrazovanje dece predškolskog uzrasta doktorska disertacija odbranjena na Filozofskom fakultetu Univerziteta u Novom Sadu.

Klemenović, J. (2007a). Filozofsko-etičko utemeljenje ekološkog vaspitanja i obrazovanja. Pedagogija LXII, 2, 182-191.

Klemenović, J. (2007b). Filozofsko-etičko utemeljenje ekološkog vaspitanja i obrazovanja drugi deo. Pedagogija LXII, 3, 374-384.

Marić Jurišin, S. (2011). Ekohumanizacija vaspitno-obrazovnog sistema i razvoj ekološke svesti na primarnom stupnju obrazovanja. Pedagoška stvarnost, 7-8, 725-740.

Markov, J. G. (1986). Socijalna ekologija. Novoibirsk: Nauka.

Marković, D. Ž. (1996). Socijalna ekologija. Beograd: Zavod za udžbenike i nastavna sredstva.

Milutinović, J. (2008). Ciljevi obrazovanja i učenja u svetlu dominantnih teorija vaspitanja 20. veka. Novi Sad: Savez pedagoških društava Vojvodine.

Milutinović, J. (2011). Socijalni konstruktivizam u oblasti obrazovanja i učenja. Zbornik instituta za pedagoška istraživanja, 2, 177-194.

Mišković, M. (2013). Novi prilog interdisciplinarnom području istraživanja - Ivan Cifrić. Pedagoška stvarnost, 59(4),711-716.

Petrović-Sočo, B. (2000). Neke suvremene stručno-metodičke osnove ekološkog odgoja u predškolskoj ustanovi. U: Uzelac, V. (ured.) (2000). Ekologija-korak bliže djetetu. Rijeka: Adamić, 43-48.

Siraj-Blatchford, J. (2009). Editorial: Education for Sustainable Development in Early childhood. International Journal of Early Childhood, 41(2), 9-22.

Stojnov, D. (2005). Od psihologije ličnosti ka psihologiji osoba: konstruktivizam kao nova platforma u obrazovanju $i$ vaspitanju. Beograd: Institut za pedagoška istraživanja.

Vasta, R.- Haith, M. M., \& Miller, S. A. (2005). Dječja psihologija: moderna znanost. Naklada Slap.

Vianna, E., \& Stetsenko A. (2006). Embracing history through transforming it: contrasting Piagetian versus Vygotskian (activity) theories of learning and development to 
expand constructivism within a dialectical view of history. Theory \& Psychology, 16(1), 81-108.

World Commission on Environment and Development, 1987. http://www.freewebs.com/odrzivirazvoj/VIII\%20cas.pdf pristupljeno 5.9.2017. 